\title{
Control and Development of Waqf Funds (Endowment funds) in Modern State "A Field Study of Jordan (Endowment) Awqaf"
}

\author{
Dr. Ziad Abdul Halim Altheebeh \\ Associate Professor \\ Zarqa University- Jordan
}

\begin{abstract}
This study aims to find common ground can build on to strengthen and activate control of the endowment (waqf) funds, and developing them to ensure performing their role as in the past.

To achieve this goal the researcher used the descriptive method, through preparing and distributing a questionnaire on the study sample consisting of 26 directorates of the Ministry of Awqaf Islamic Affairs and Holy Places, 50 questionnaires were distributed on the employees of the Ministry, who form the study sample.

The study concluded that control and oversight of waqf funds in the Jordanian state are weak, and consequently the development of these funds is weak too. Thus, this requires the researcher to recommend the need to create perfect control procedures to support the role of Waqf (endowment) and develop it to come back to its golden days and to be useful in all walks of life, including economic.
\end{abstract}

\section{Procedural Definitions}

Control: Administrative and financial procedures followed regularly to achieve preserving the assets of institution from loss or theft.

Development: Followed procedures used for controlling funds and investing them with the best available methods to achieve maximum revenues with a minimum costs.

Waqf (Endowment): Donating a fixed asset, like real estate, buildings or others to the Ministry of Awqaf, so that the Ministry keep them and benefit from their revenues.

\section{General Framework of the Study}

\section{INTRODUCTION}

Islamic religion with its tolerant teachings, roomy prospects and wide comprehensiveness is considered the greatest religion, the most right and valid for every time and place as well as it addresses the problems of nations and peoples and describes them the efficacious cure.

The endowment is considered of the Muslim community features and one of its most important systems in achieving social and economic development. Jurists has taken care of endowment and established for it provisions governing its transactions to protect its funds, developing them and continuity of providing their benefits to the beneficiaries according to the purposes of al-wāqif (founder) contained in endowment document (Shhatah, 2003).Islam developed economy greatly and gave security for each one shaded by it, as well as it gave safety and prosperity in living. consequently, hardly you can see poor or in need person in the era of Islam's prosperous days through the depths and our evidence here is the era of Omar Bin Abdul Aziz, who did not find any poor, slave or a bachelor to take from that exceeded in the Muslims' Treasury.

The importance of endowment that it is considered the most important cornerstone of the Islamic economy bases that give benefits for the individual, society and the nation, and this is clear witnessed by the history in the past and at present. It has covered all aspects of life, like the educational, healthy, charitable endowment, and building towns, cities, public services and infrastructures .It was actually an important sector parallels the public and private sectors. It should be noted that the movement of endowment was affected by the recovery and retraction of the prevailing political systems, where they were in the first centuries and until the nineteenth century in recovery, but they had retracted and declined of the last century and so far. States and governments took the possession of the endowment, so it was no longer able to generate neither cash capital nor the fixed social capital or the productive capital as it was before, therefore we lost the positives and benefits of this system, in spite of their significance and our need for them. (Kahaf, 2000). 
Thus, if want to return the endowment back to its glory and effectiveness in the society, it is essential for researchers in this area to stand on the reasons leading to its decline, and explore suitable means to advance it, hence this study was conducted to illuminate the reality of control and development of the endowment in the modern state.

\section{SignifiCANCE OF THE STUdY}

- To highlight the effective role of the endowment in supporting the state to do its duty to towards society.

- Knowledge of control level over endowment funds and its development level.

- Recognizing ancient and modern methods used in developing endowment funds and diagnosing weaknesses and strengths points in these methods to choose the best method, through studying endowment (Awqaf) in Jordan as a model for control of endowment and developing it.

\subsection{Study Objectives}

This study aims to:

- Recognize the significance of endowment in increasing wealth and whether it is considered imprisonment of wealth and freezing of it.

- Make certain that there is a actual and effective control on endowment funds in Jordan.

- Check that there is a development of endowment funds in Jordan and find out the effectiveness of the taken procedures in achieving this goal.

\subsection{Study Problem}

Through examining the reality of endowment (Awqaf) in Islamic countries in the world and recognizing its deep impact in economic and social life in Islamic societies over time and in many centuries, in which Islam ruled, we find that, this reality does not reflect what the endowment should be of development, investment and control, as a result this study attempts to answer the state of control and development of the endowment in the modern state, namely Jordan through the following questions:

1. Is there an effective control over the endowment funds in Jordan?

2. Is there an effective development of the endowment funds in Jordan?

\subsection{Study Hypotheses}

The researcher formulated the study problem in the form of two hypotheses, as follows:

HO1: First Hypothesis: There is no effective control over the endowment funds in Jordan.

HO2: Second Hypothesis: There is no effective development of the endowment funds in Jordan.

\subsection{Study Population}

Study sample consists of 26 directorates of the Ministry of Awqaf Islamic Affairs and Holy Places.

\subsection{Study Sample}

The study sample was selected randomly of the administrative employees in the directorates mentioned above, where sixty questionnaires were distributed to this population. 50 questionnaires were answered and these represent $\% 83$ of the study sample.

\subsection{Literature Review}

1. Khoja Study (1996) "General View of Endowment and Development in the Past and at Present", the Royal institute for Islamic civilization Research. The researcher studied in this study the importance of endowments in the past and at present improving societies and developing them. In addition he compared investment of endowment in the past and at present and came to a result that endowments in the past had a great role in developing the state economically and socially, while this role is now less than the past.

2. AlAbed Allatif Study (2002) entitled: (The Impact of Endowment on Economic Development). The study aimed to emphasize the role that the endowment play in developing society and 
supporting it economically, through explaining the business that the endowment contributes to Islamic society and economic analysis of those contributions to see their impact in supporting economy and developing it, so this study reached to a set of results, including:

- Endowment contributes to the religious, cultural, social and economic aspects of society and others.

- Endowment as an economic source is able to influence on development as it represents financial revenues gained from the state, in addition to its contribution increasing agricultural, industrial and commercial production.

- Endowment has an impact on treating economic problems such as unemployment. The author came out with several recommendations including:

- Doing overall enlightenment in Islamic society to explain the role and importance of endowment and expanding its concept to include various activities through conferences and seminars.

3. Malik Study (2002) entitled (Developing and Conserving Endowment Resources) this study examined the importance of developing endowment resources and preserving them through the following aspects: Forms of Islamic solidarity, Foundations of developing endowment resources and preserving them.

The study reviewed forms of means of developing endowment resources and the importance of studying the economic feasibility in developing endowment resources. The study concluded several recommendations, the most important of these are: establishing an independent charity to supervise the endowments. It also recommended that this independent charity should have several funds, including an endowment fund to take care of the family, an endowment fund for culture and thought, an endowment fund for health care and the endowment fund for preserving environment.

4. Khatib Study (2002) entitled (Impact of Endowment in Economic Development) this study shows the impact of endowment in developing the society economically and focusing on the role of society not the state in developing the endowment.

This study followed the inductive approach to demonstrate the impact of economic development through several topics, the most important of these are: the concept of economic development, its importance, the impact of endowment on it and the developmental dimension of endowment.

The study found out that endowment role is apparent in economic development and that there are economic areas that can develop endowment funds to raise the level of general welfare.

In addition, the study recommended giving life to Endowment Sunna, giving attention, organizing and managing it in a scientific way to perform its mission, which is found for it, in order to obviously show its clear developmental impact.

\section{THEORETICAL FRAMEWORK}

\subsection{Endowment (Waqf) in Sharia (Islamic Law)}

\section{- Endowment Definition:}

Sayyed Sabek says that (1997, p. 515) Endowment in language means: mortmain, it is said to endow, which means endowment, but the word I endowed is abnormal. It is said to endow, which Hadith says: "If you want to endow its origin or you have the choice to give it to charity". And in AlMo'gam Al-Waseet (Arabic Dictionary) mortmain means: "prevention and abstention". And the plural of endowment is endowments and the plural of mortmain is mortmains. Additionally, as in Zakatww (Almsgiving) Speech that khaled (May Allah be pleased with him) made his armours and war weapons endowment for the sake of Allah, so as to be away from jurists' arguments. The researcher agrees with Mr. Nazih Hammad's opinion, who favored the definition of the authors of the books (AlMuqanna and AlMoghni): "Endowing the origin and mortmain of benefit" (Nazih Hammad, 1995, p. 353).

\subsection{Legitimacy of Waqf (Endowment)}

The legitimacy of endowment origin is constant in the Holy Qur'an, Sunna and consensus. Allah legislate endowment, ask to do it and make it permanent good deed, the servant of Allah can do it to obey Allah to be a constant charity in his life and after his death. 


\section{First: The Holy Qur'an}

Allah says: "By no means shall you attain Al-Birr, unless you spend of that which you love" (AlImran 92.3).

Allah says: "... and do good that you may be successful" (Al-Hajj 77.22)

\section{Second: the Sunna}

In Sunna there are many in prophetic speech reported about the legitimacy of the endowment, which confirms that it is sure. In Pre-Islam people did not know endowment, but when Islam came, it called for it, made it a charity to be loved by the poor and it was legitimated as a sympathy to the needy, this is due Abu Huraira (May Allah be pleased with him) reported that the Messenger of Allah (Peace be upon him) said, ("When a man dies, his deeds come to an end except for three things: Sadaqah Jariyah (ceaseless charity); a knowledge which is beneficial, or a virtuous descendant who prays for him (for the deceased)." (Narrated by Muslim, Abu Dawood, Attarmadhi, Alnessaee and Al-Bukhari in AlAdab Almufrad, Saheeh Aljamee Alsagheer 1/279, investigation of Naser Adddin Al-Albani, 1969).

How to spend the Endowment: (Kahf, 2000, p. 158)

It means the beneficiary parties of the endowment:

1. Supporting private, public and professional educational institutions, and the establishing public and specialized libraries.

2. Helping male and female students to study at home and abroad.

3. Supporting scientific research institutions.

4. Taking care of the elderly and orphans.

5. Looking after the Disabled, the idiotic and the institutions that serve them.

6. Protecting childhood, maternity and taking care of family.

7. Assisting the poor, the needy and other low-income people.

8. Providing technical and scientific training for those who need it to increase their production and income.

9. Providing public services, like water, electricity and sanitation to the poor, the wayfarers and others or to people in their cities and villages.

10. Lighting streets and roads as well as preparing them for pedestrians and cars.

11. Helping Imams, Orators and Servants of mosques.

12. Building mosques, furnishing and providing them with books and Holy Qurans as well as spending on Servants, Imams and Teachers, and on other expenses.

13. Supporting health care projects and help patients.

14. Providing material support for endower, his family, his clan, his neighbors and his inheritors or some of them, and other persons (The endower mentions them by naming them, reporting their attributes or relative links) and to support the needy.

15. Taking care of animal, environment and general cleanness.

16. Fighting crime.

17. Improving traffic systems and traffic on the streets of cities and villages.

18. Supporting the defense efforts of homeland and nation.

19. Giving support to Islamic Call inside and outside the country.

20. Building charitable hospitals.

21. Establishing charitable universities and intermediate colleges.

22. Constructing bridges, roads and tunnels and paving them.

23. Building commercial markets. 
We most of the time deal with endowment in a stereotypical image, which means endowing the endowment itself, while keeping its utility going on. Thus, the origin of endowment is not sold or bought, but it remains endowed to the party that the endower assigned. For example, someone endowed a land and a building for the benefit of orphans; this endowment remains to serve orphans without development that means it is possible to support other endowments, that is endowments can support each others. This can be achieved by community enlightenment of the importance of endowment at first, which contributes in restoring work and the reward after death through employing and developing it for the benefit of society, and in support of serving endowments among themselves in an integrated way.

Endowment in favor of education like its buildings and other, it is possible to support it with another for the benefit of scholarships. In addition, endowment for the benefit of mosques can be supported by another endowment for the benefit of libraries and equipment in the mosques. Health endowment can be supported by another endowment to support medical research in certain areas.

\subsection{Developing Endowment and Controlling it}

With what we see nowadays of economic developments, techniques and modern investment tools, it is essential to make use of these tools and in accordance with Islamic Sharia in investing and developing endowment funds. Although investment in endowment funds is a controversial issue among jurists, scientists and researchers in terms of used tools.

We tend to agree with Aldori, Khoja and other researchers' view of legality of investing and developing endowment funds based on legitimate modern methods.

Aldori says (1996, pp. 109 -110) "On the one hand, we can see legal opinions permitting depositing endowment funds in Islamic Banks, so that they can be invested in ways that have not been studied by scholars well yet, permitting endowment of companies' shares or bonds in a national loan, investing them in hotels and others or borrowing from abroad to finance endowment projects".

Khoja says (1996, p. 185) "On the other hand, we tend to the view that says endowment funds are increasing and their revenues exceed their costs, otherwise it is not accepted as an endowment originally. Endowment does not need external funding or urgent action and if the contrary happened, this will be due to the corruption of supervisors, rulers, scientists or methods of controlling endowment because the basic principle is that the state borrows from endowment not vice versa".

There are various forms to invest endowment funds, we choose among these based on the nature of funds oriented towards investment, according to circumstances prevailing at the time of investment decision-making and in the light of legitimate controls and investment standards previously declared in details.

\subsection{These areas can be divided into the following groups}

First - Real Estate Investment: this scope includes for example, the following:

- Purchasing real estates and leasing them, so that people benefit from its profits and revenues.

- Construction, maintenance and renewal of old real estates, which are about destruction as stated from the technical, economic and social studies for the feasibility of these.

- Replacing old real estate with new ones when technical, economic and social studies have verified their feasibility.

- Constructing buildings on endowment lands based on system of tooling, participation, participation ended with ownership, ground rent or any form of investment formats.

Second - Investment in Creating Productive Projects: These projects are professional and small crafts operating in necessities and needs field, so as to achieve the greatest possible benefit for beneficiaries that contribute to the social and economic development and this may include for example, the following:

- Small craft projects.

- Small professional projects.

- Poor family resources development projects. 
Third - Investment in Service Projects: Like educational, medical, social projects and these for example, may include the following:

- Qur'an recitation offices, religious institutions and Islamic schools.

- Clinics and popular health centres and so on.

- Guest houses for the poor, the needy and the wayfarers.

- Orphans, the elderly and the sick houses.

Fourth - Investment in Securities: This is in order to gain relatively constant lawful returns with certain conditions, controls and standards that have been explained previously, and the most important of these are:

- Ordinary shares of stable companies operating in good lawful area with few risks.

- Islamic Sukok issued by Islamic financial institutions.

- Participating bonds in profit and loss with secure and stable nature.

- Sukok of Islamic investment funds.

- Endowment funds bonds in the sister states.

- Muqarada bonds issued by Islamic financial institutions.

Fifth - Investment in Islamic Financial Institutions: through investment accounts for term, such as, for example:

- Investment bank books on demand.

- Term investment deposits.

- Investment certificates with absolute fixed term.

- Investment certificates with restricted fixed term.

- What has the same rules of legitimate lawful developments.

Sixth - Investment in Agricultural Activities: for example, the following:

- Leasing endowment agricultural lands.

- Participating in the utilization of some endowed agricultural lands.

- Participation in growing and exploiting some endowed agricultural lands.

Seventh: Selling some endowed real estates and buying a new real estate instead of them that to be assigned for the first endowed parties (that owned the first real estate).

Eighth: Selling one endowment to build another one unites with it in serving the same beneficiaries.

Ninth: Selling of a number of endowments and buying a new real estate with a high profit, that to be distributed on the sold endowments with suitable value.

\subsection{Endowment Management}

Ghanem says (Ghanem, 1999) "Our Arab and Islamic societies knew the endowment system from the early years of Islam, and over the years it became a system with integrated basic elements of administrative, functional and legislative aspects. Despite of the large number of developments that it witnessed and the deep social transformations that have occurred within it, particularly during the modern state and from the beginning of the nineteenth century at least, but it characterizes with a large extent of autonomy and relative efficiency in most of Arab and Muslim countries, in particular in the period between the second half of the nineteenth century and the first half of the twentieth century. After that, this system began to grow weaker, its institutions became lean, lost a lot of its functions, its effectiveness decreased and its basic elements deteriorated in a clear way, and this was almost since the mid-twentieth century. We cannot attribute this to a single cause, but there are many reasons, some of them are historical, like the legacies periods of civilization decline that hit Islamic 
communities, others are political- legal, came as a result of " changing the relationship between the society and the state, and the authority of this state extended with its ramified bureaucratic organizations to various aspects of social life, including the endowment and its institutions.

In addition to, the intervention of modern state authority to codify endowment provisions and reformulation its legislative framework through a series of laws and regulations, which eventually led to integrating of "Endowment System" with its institutions and activities in the government bureaucracy departments.

We have now in the Arab and Islamic countries an enormous amount of money and real estate, which is endowed for charitable purposes and general benefits, but the current state of this amount generally - require doing a serious reform movement in legislative legal aspects of the endowment system, in administrative and institutional systems and in public policy to employ the returns of these endowments, particularly the endows run by the Ministries of Awqaf as well as to promote the initiative of establishing new endowments.

"We can see that the funds and reality of the endowment now, and after fifty years of practicing the Ministries of Awqaf authority on endowment proves the failure of government administration in achieving endowment objectives, advancement of its mission and ensuring its continuance, in addition, to achieving the interests of beneficiaries and local environments, and all this shows the failure of endowment in the past and the calls, resolutions and laws of cancelling it, still need for prove and evidence "(Al-Husseini,1996, p. 28).

All of the above leads us to say that individual management of endowment has received all advantages of the required administration of endowment to achieve the objectives of the endowment, providing funds and the cost of labor, job security and efficiency of performance, continuation of endowment and its message, serving local community and other advantages, which is the from the choice of Allah, where Allah, the Almighty said regarding endowment "and giveth wealth, for love of Him" (Qur'an, 2,177). Here the speech format shows the choice of endower, which means the endower, has the choice to give money to those whom he loves, for example for his relatives. This will not be achieved if the government has control over the endowment fund or it is under the authority of any other department regardless of how it is neutral and fair, other than those the endower have chosen.

Kahf says (Kahf, 2000, pp. 122-123) "That the government administration - by its very nature Neither it is suitable for economic institutions nor for institutions of charity, compassion and beneficence ... people have known it, whether they are thinkers such as Ibn Khaldun, who called for the government not to be a merchant, or through tragic suffering, sacrifices and many pains that caused by the situation that the government has taken the responsibility of managing economy and the distribution (and charitable works of all their types) in the society, which is still visible in many countries ...

\subsection{Endowments Fixed Assets (Abdullah, 2010)}

Fixed assets are assets that the establishment acquires in order to use it in its operational processes and not for reselling it and it is acquired for a period more than one year or for the operational circle whichever is longer and some of these tangible fixed assets and intangible. Tangible fixed assets include real estates, improvements, buildings, equipment and others. Fixed asset to be recorded by the cost of gaining it, according to basis of historical cost and the cost is measured by cash value paid for acquiring it or the cash price equivalent to the value of other assets that have been exchanged for the purchased asset. This usually equals the fair market value of purchased fixed assets or assets that have been waived whichever is clearer.

\subsection{Control Procedures over Endowments as Fixed Assets (Althunaibat, 2010)}

Specific objectives are achieved by auditing fixed assets by following these procedures:

1. The first goal is achieved by actual inventory of fixed assets, whether by counting, viewing, measurement or similar to that. A request is issued to the project management to provide the auditor with detailed statements of these assets and what happened of them lately of additions and whole or in part depreciations. 
2. To be sure of possession by access to documents proving ownership of the enterprise of asset, like purchase invoice or construction contract plus any documents related to additions to the original documents, as can be ascertained from the property, and in certain cases of private assets. Moreover, in certain cases by external sources, as in real estate from (Department of Land \& Survey) and cars from( Driver \& Vehicle License Department or Traffic department) and auditor shall also make sure of total depreciation of some assets, which means deleting some assets of existence and that those records and decisions regarding depreciation is intentional accredited by the competent party.

3. Checking the validity of assessment by taking into consideration the following:

- Auditing fixed asset records to be sure that they are correct and contain all the terms of these assets.

- Verification of depreciation methods and with generally accepted rates and applying them consistently.

- Taking care not to confuse between capital expenditures or revenues connected to fixed assets. Maintenance expenses may be sometimes revenues and other times may be capital expenditures depending on their size and financial project policy towards it.

- Taking into account that fixed asset cost includes purchasing price or contract plus all expenses until that the asset becomes utilizable.

\subsection{Research Methodology, Tests, Results and Recommendations}

\subsubsection{Data Collection Method}

The researcher based on two sources of data collection for data and information collection method, so that this research comes out in its final form:

\section{A- Secondary Sources:}

All articles, books, literature, periodicals, reports and previous research related to the study subject.

\section{B- Primary Sources:}

The researcher finds out that the appropriate instrument to measure variables is the questionnaire, which is a suitable instrument, through which we can get information, data and facts related to the subject under discussion. The researcher designed a questionnaire for this purpose consists of 20 questions; each answer to each of these questions is rated on a 5-point scale 1 - 5. (SPSS) software was used in preparing the statistics of this study. In addition, for the purpose of testing the hypotheses of the study, the researcher adopted a measure for degree evaluation of the study sample participants and it is divided into three levels, where the cut-off score was calculated by dividing the product of the difference between the highest value of the scale (5) and the lowest value in it (1) on three levels, namely, the cut off score is as follows: $\{(5-1) / 3=1.33$. Thus, the three levels are:

Low score (2.33 - 1).

Medium score (3.67 - 2.34).

High score (5 - 3.68).

The questionnaire consisted of three sections:

First Section: the demographic data was collected about the participants in the questionnaire questions (educational qualification, scientific specialization, career position, years of experience in banking business) in order to determine the extent of knowledge and perception of the participants of the questionnaire contents and their ability to answer its questions.

Second Section: its purpose to measure the extent of availability of control over endowment funds through questionnaire questions from the first question to the tenth question.

Third Section: it deals with measuring the amount of the existence of real investment and development of endowed funds in the Ministry of Awqaf through questionnaire questions from question eleven to twenty.

The second and third sections of questionnaire were formulated in a form that shows the simplicity of measurement.5-point Likert scale was used as a measure (very high, high, moderate, low, very low). 


\subsection{Instrument Validity and Reliability}

To confirm of statistical validity of the questionnaire, two tests of was used checksum validity and reliability were used as following:

A-Instrument Validity: validity test shows the extent of the questionnaire to test the variables that it was assigned for them; therefore test validity has been done through:

Arbitrators: to take into consideration comprehensiveness of the questions and avoiding duplication as well as showing the questionnaire to specialists from academics and professionals to check its feasibility.

B- Instrument Reliability: This is to measure the extent of access to the same data if the questionnaire is repeated more than once. Therefore, Cronbach's alpha measure was used to determine reliability ratio of stability, where the questionnaire will be accepted if the reliability ratio exceeds $60 \%$. Through analysis, it was found that reliability ratio is about $80 \%$ and so, the results of the questionnaire are reliable and valid in achieving study objectives.

\subsection{Population and Sample of the Study}

Study population: consists of employees of Ministry of Awqaf Islamic Affairs and Holy Places with its departments in various administrative levels. The sample size reached 60 persons. The questionnaires were distributed and the number of returned questionnaires and approved for the purposes of research and analysis was (50) questionnaires with a percentage of $83 \%$ of the distributed questionnaires. The distribution included departments' directors, heads of departments and personnel responsible for endowment, whether in the Ministry or in its departments in the entire Kingdom.

\subsection{Statistical Analysis}

For the purposes of statistical analysis Statistical Package for the Social Sciences (SSPS) was used according to 5-point Likert scale coefficient as well as the significance level of 0.05 was used. Additionally, a focus was given to the use of the arithmetic mean, standard deviation and one sample t-test. The results of the statistical analysis are as follows:

\subsection{Results Related to Answering Study Questions}

This section contains an analysis of responses of the study sample by answering the study questions and reviewing the most important results of the questionnaire, which was attained by analysis its items. The researcher used arithmetic means, standard deviations, the relative weight and significance of the item. In addition, one sample t-test was conducted to analyse items of the questionnaire. Item is to be positive if the participants agree with its content, if calculated t-value is greater than t-tabulated which equals 1.67 or the significance level is less than $(\alpha \leq 0.05)$, Item is to be negative if the participants disagree with its content, if calculated t-value is less than t-tabulated which equals 1.67 or the significance level is less than $(\alpha \leq 0.05)$ and the participants 'views in the sample to be neutral if the significance level is greater than $(\alpha \leq 0.05)$.

\subsection{1- Results related to Testing the First Hypothesis}

\section{First Hypothesis: There is no effective control over endowment funds in Jordan}

To test this hypothesis, t-test was conducted for differences among item mean, neutral mean (3), arithmetic means and standard deviations of the answers of the study sample in the departments of the Ministry of Awqaf in Jordan, in order to identify the extent of study sample interest in each of the questionnaire items and to diagnose the extent of answers dispersion from their arithmetic means.

The results showed that the arithmetic mean of all the items of this question is equal to (2.18), calculated t-value equals (-6.76), which is smaller than $\mathrm{t}$ - tabulated that equals (1.67) and the significance level equals $(\alpha=0.00)$ which is less than $(\alpha \leq 0.05)$, which means that the participants disagree with the content of the questions addressed to them that there is effective control over endowment. Ultimately, this means accepting the null hypothesis that states there is no effective control over endowment funds in Jordan.

\subsection{1- Results related to Testing the Second Hypothesis}

\section{Second Hypothesis: There is no effective control over endowment funds in Jordan}

To test this hypothesis, t-test was conducted for differences among item mean, neutral mean (3), arithmetic means and standard deviations of the answers of the study sample in the departments of the 
Ministry of Awqaf in Jordan, in order to identify the extent of study sample interest in each of the questionnaire items and to diagnose the extent of answers dispersion from their arithmetic means.

The results showed that the arithmetic mean of all the items of this question is equal to (2.13), calculated t-value equals (-5.83), which is smaller than t- tabulated that equals (1.67) and the significance level equals $(\alpha=0.00)$ which is less than $(\alpha \leq 0.05)$, which means that the participants disagree with the content of the questions addressed to them that there is effective control over endowment. Ultimately, this means accepting the null hypothesis that states there is no effective control over endowment funds in Jordan.

\section{RESUlTS AND RECOMMENDATIONS}

\subsection{First: Results}

1. Islamic Endowment (Waqf) Foundation has played an important and a major role in supporting nation's economy, developing society and achieving cessation the message of endowment in the past.

2. Relapse of the endowment importance at Islamic Peoples in this century, this was because of the intervention, control and management of Islamic Countries of endowment.

3. Endowment is an increasing fund and originally, its revenues exceed its costs, furthermore it was and is still an Islamic financial resource that supports economic and social development of Islamic society.

4. There is an omission by the Ministry of Awqaf of investing in endowment by using modern and advanced methods.

5. Weakness of controlling endowment by the institution responsible for it.

6. There is an omission by the government in the developing endowment funds.

\subsection{Second: Recommendations}

1. Current circumstances that societies experience in the Islamic world, requires action to support the role of endowment to contribute supporting social, charitable and economic work.

2. Bringing back individual management to endowment under supervision of the judiciary.

3. Endowment funds are social funds achieves in interest of society, and this requires creating control and auditing endowments' accounts periodically and in a planned method as well as this should be obligatory and to assign the task to the auditing offices in the private sector, which are its work founded on auditing rules recognized internationally. Beneficiaries shall share judges in selecting auditing offices or firms for these tasks and receive their reports as well as to determine their fees within fees that the endowment committed with them.

4. Searching for modern methods for developing endowment funds and investment in them according to provisions Sharia.

5. Making a periodic inventory endowment funds and encouraging increasing endowment to achieve social wellbeing.

6. Establishing future plans and studies for developing endowment funds.

7. Using more accurate and efficient accounting system that helps in control and monitoring endowment funds.

\section{REFERENCES}

[1] Al Husseini, Mohammad Asa'ad Allmam. Pure reference of endowment and its provisions. Beirut ed, Jerusalem: Abu Arafa Agency, 1982.

[2] Hammad, Nazeeh. Dictionary of economic terms in the language of jurists. International Institute of Islamic Thought, United States: 1995.

[3] Althunaibat, Ali Abduqader Hassan. Auditing in the light of international auditing standards: Theory and Application. 3rd ed. Amman: National Library, 2010.

[4] Sabeq, Sayyed. Jurisprudence of Sunna. $1^{\text {st }}$ ed. Part 1. Beirut: Dar Alketab AlArabi, 1971. 
[5] Abdullah, Khalid Amin. Auditing science. Theory and practice. Amman: Dar Wael for publication, 2010.

[6] Kahf, Monther. Islamic Endowment: Its development, administration and increasing. $1^{\text {st }}$ ed. Damascus: Dar Al Fekr, (2000.

[7] 7.Al Kubaisi, Ahmad. Jurists' companion. Jeddah: Dar Alwa'a for publication and distribution, 1990.

[8] Alomari, Mohammed Ali. (1993). Forms of investment in endowment properties. (Unpublished master's thesis). Yarmouk University, Irbid,

[9] Kabha, Sufian Nawaf. (1999). Provisions of mosques' endowment. (Unpublished master's thesis). An-Najah National University, Nablus.

[10] AlKhatib, Mahmoud. Impact of endowment on economic development. A research presented to the first Conference of Endowments in Saudi Arabia. Umm Al Qura University, Makkah: 2002.

[11] Khoja, Mohammed Alhabib. An overview of endowment and development in the past and at present. Royal Institute for Islamic Civilization Research. London: 1996.

[12] Aldawood, Abdul Aziz Bin Mohammed. Provisions and characteristics of endowment. Journal of Sharia lights. Vol.11. Riyadh: ( AH 1400).

[13] Aldori, Abdul Aziz. A seminar of the importance of Islamic endowments in today's world. Royal Institute for Islamic Civilization Research. London: 1996.

[14] Albdullatif, Abdul Latif. Impact of endowment in economic development. A research presented to the first Conference of Endowments in Saudi Arabia. Umm Al Qura University, Makkah: 2002.

[15] Alghanim, Ibrahim Albayyomi. Endowment and contemporary forms for national work. Journal of society. no.1328, 1999.

[16] Shehata, Hussein Hussein. Investment of endowment funds" Awqaf Magazine, A research presented to the first Forum of juristic issues of endowment funds. Kuwait: 11 to 13 October 2003.

[17] Shehata, Hussein Hussein. Islamic method to study of investment projects feasibility. A study presented to Faisal Islamic Bank of Egypt. Management of research and training, with acting according to the nature of endowment funds 1992.

[18] Malek, Saleh. Developing endowment resources preserving and them. A research presented to the first Conference of Endowments in Saudi Arabia. Umm Al Qura University, Makkah: AH 1422.

[19] Almasri, Rafiq Younis. Is it permitted to substitute endowment in order to maximize the revenues.," Islamic Economics Magazine no. 202, 1998. 